\title{
II. Meşrutiyet Dönemi Osmanlılık Düşüncesinin Evrimi: Abdülkadir Câmi (Baykurt) Bey Örneği
}

\section{The Evolution of The Second Constitutionalist Period Ottomanism Thought:The Case of Abdulkadir Câmi (Baykurt) Bey}

\author{
Bahattin Çatma a,* \\ ${ }^{a *}$ Dr. Öğr. Üyesi, İnönü Üniversitesi, Fen Edebiyat Fakültesi, Tarih Bölümü, 44000, Malatya/Türkiye. \\ ORCID: 0000-0002-1180-0586
}

\section{MAKALE BİLGISİ}

\section{Makale Geçmişi:}

Başvuru tarihi: 04 Şubat 2019

Düzeltme tarihi: 20 Şubat 2019

Kabul tarihi: 01 Mart 2019

\section{Anahtar Kelimeler:}

Osmanlılık,

Abdülkadir Câmi (Baykurt) Bey,

II. Meşrutiyet Dönemi.

\section{ÖZ}

Tanzimat Fermanı'nın ilanının ardından Osmanlı Devleti'ni Fransız İhtilali sonrası dönemde dünya üzerinde etkinliği artan milliyetçilik cereyanının etkisinden kurtarmak maksadıyla ileri sürülen ve oluşturulması murat edilen temel düşünce Osmanlı Milleti yaratma düşüncesi şeklinde tezahür etmiştir. Osmanlılık ya da Osmanlı Milleti yaratma teşebbüsünün, önceleri devlet politikası olarak benimsenen, sonraları dönemin münevverleri nezdinde kabul gören ve devleti selamete erdirmenin imkânı olarak fikrî muhtevaya bürünen bir teşebbüs haline geldiğini söylemek pekâlâ yanlış olmaz. Bu teşebbüs; Balkan Savaşları sonrasında büyük oranda geçerliğini yitirmiş olmakla birlikte, belirli bir takım unsurların birlikteliği üzerinden varlığı devam ettirilmek istenen bir hal almıştır. Bunun bir örneği de Trablusgarp Savaşı'na fiili olarak katılıp, Meclis-i Mebusan'da mebusluk ve Türkiye Cumhuriyeti'nin ilk İçişleri Bakanlığı gibi görevlerde bulunan, bu bakımdan hayatı boyunca Türk siyasetinde etkin bir rol oynayan Câmi (Baykurt) Bey'dir. Bu çalışmada; Câmi (Baykurt) Bey tarafından 1913 yılında kaleme alınan Osmanlılığın Atisi, Düşmanları ve Dostları isimli eserden hareketle dönem itibariyle Osmanlılığa ilişkin serdettiği fikirlere temas edilmeye gayret edilmiştir.

\section{ARTICLE INFO}

\section{Article history:}

Received 04 February 2019

Received in revised form 20 February 2019

Accepted 1901 March 2019

\section{Keywords:}

Ottomanism,

Abdülkadir Câmi (Baykurt) Bey,

The Second Constitutionalist Period.

\begin{abstract}
A B S T R A C T
After the proclamation of the Rescript of Gulhane, the basic thought which was suggested with the purpose of saving Ottoman Empire from the effect of nationalism that has increased its effectiveness around the world in post-French Revolution era and wanted to generate, appeared as the thought of building an Ottoman Nation. It wouldn't be wrong to say that Ottomanism or the attempt of building an Ottman Nation became an attempt which was adopted as a government policy at first, was accepted by the intellectuals of that period and came in an intellectual content as a possibility of salvation of the empire afterwards. Although this attempt lost its validity to a large extent after the Balkan Wars, it wanted to be continued through the togetherness of a number of certain elements. An example of this is Câmi (Baykurt) Bey who attended to Trablusgarp War actually, hold offices like being a deputy in Turkish Parliament and being the first interior minister of Republic of Turkey, in this regard played an active role in Turkish politics throughout his life. In this study, it is tried to touch to toughts concerning the Ottomanism that were suggested wtih referance to book Osmanlılığın Atisi, Düşmanları ve Dostları written by Câmi (Baykurt) Bey in 1913.
\end{abstract}

\section{Giriş}

Fransız İhtilali sonrası dönemde dünya üzerinde etkinliği ve geçerliliği olan fikir hiç kuşkusuz milliyetçilik olmuştur. Unsurların farklılığından müteşekkil olan imparatorlukların söz konusu fikirden etkilenmeleri kaçınılmazdır. Bu bakımdan imparatorlukların varlıklarını muhafaza etmeye dönük duyulan zaruret beraberinde belirli çözümler üretmeyi elzem kılmıştır. Osmanlı Devleti de farklı din, mezhep ve etnik unsurları bünyesinde barındırmasından ötürü bu durumdan etkilenen dönemin devletlerindendir. Hal böyle olunca ilk olarak Osmanlı devlet adamları tarafindan Osmanlılığ

\footnotetext{
* Sorumlu yazar/Corresponding author

e-posta: bahattin.catma@inonu.edu.tr
} 
merkeze alan ve müşterek vatan fikri etrafında şekillenen çözümler üretilmeye gayret edilmiştir. 1829 kıyafet düzenlemesini, Tanzimat ve Islahat Fermanlarını ve 1864 Vatandaşlık Kanunu gibi düzenlemeleri bu çerçevede değerlendirmek yerinde olacaktır (Çalen, 2013: 89). Bu noktada Osmanlılığın ne olduğuna dair her ne kadar farklı ifadelerle muhtelif tanımlar yapılsa da en temelde murad edilen husus imtizaç-1 akvam olmuştur.

Osmanlı'nın son döneminde kaleme alınan metinlerde de kabaca imtizaç-1 akvam adlandırması üzerinden bir anlam bulan Osmanlılık/Osmanlıcılık düşüncesinin 19. yüzyılın ilk çeyreğinden itibaren görünür olmaya başladığını belirtmek gerekmektedir. Nitekim Yazıcı'nın (2002: 28-33) Tanzimat ve Islahat Fermanlarının muhtevasında barındırdığı eşitlik prensibinin Osmanlılık fikrine istinat ettiğine dair yaptığı vurgu dikkat çekicidir. Sultan II. Mahmut tarafindan ifade edilen ve farklı dinlere-mezheplere mensup olan insanların farklılıkları ile varlıklarını devam ettirebilmelerine ilişkin olan atıf bu bakımdan modern bir düşünce olarak Osmanlılık/Osmanlıcılık fikrinin membaı olarak o döneme işaret etmemize imkân tanımaktadır. Burada belirtilmesi elzem olan hususların başında ise Osmanlılık düşüncesi ile murad edilenin tamamıla Fransız İhtilali sonrası dönemde dünya üzerinde geçerli hale gelen milliyetçilik karşısında Osmanlı Devleti bünyesinde yaşayan insanları Osmanlı Milleti olarak tesmiye edip devleti bu muhtemel tehlikeden azade k1lma gayreti olduğudur. 19. Yüzyılın ilk çeyreğinden itibaren geçerli olmaya başlayan bu durum Osmanlı Devleti'nin nihayete erdiği 20. Yüzyılın ikinci çeyreğine kadar geçerliliğini muhafaza etmiştir. Ancak şunu da belirtmek gerekir ki; her ne kadar Osmanlılık siyasî bir çaba olarak var olmuşsa da söz konusu zaman aralığında yaşanan belirli hadiseler sebebiyle farklı tezahürlerle varlık göstermiştir. Hatta öyle ki "Osmanlı milleti” teşekkül ettirme arzusunda olan Osmanlı aydınlarının yer yer bu fikirlerinden beri durmaya başladıklarını ve dikkatlerini gayri Müslimlerden kaçırarak Müslüman tebaaya yönelttiklerini belirtmekte fayda vardır (Mardin, 1996: 367-368).

Osmanlı1ı/Osmanlıcılık düşüncesinin söz konusu farklılıklarından ötürü tarihi süreç içerisinde dönemlendirmelere ayrılabileceğini de belirtmek gerekmektedir. ${ }^{1}$ Özellikle Balkan Savaşları sonrasında ortaya çıkan durum sadece Osmanlılık düşüncesi için değil aynı zamanda diğer fikri tezahürler için de muhasebe, inşa ve farklılıkları ile tebarüz etme imkânını bir zaruret olarak ortaya çıkarmıştır. Nitekim gerek II. Meşrutiyet koşullarının gerekse Balkan Savaşları sonrasının ortaya çıkardığı durum fikri tezahürler arasında çeşitli münakaşaları beraberinde getirmiş

\footnotetext{
${ }^{1}$ Bu hususta meseleyi vuzuha kavuşturmak bakımından Somel (2001:90) tarafindan yapılan dönemlere ayırma gayreti dikkat çekicidir. Somel; modern bir düşünce olarak Osmanlılık/Osmanlıcılık düşüncesinin Tanzimat Fermanı'nın ilanı ile birlikte gelen süreçte Mustafa Reşid, Âli ve Fuat Paşalar tarafindan ortaya konulan yenilik teşebbüslerinin olduğu dönem, Yeni Osmanlılar ve bazı devlet adamları üzerinden belirginleşen Kanun-i Esasîye ilişkin çabaların olduğu dönem, II. Abdülhamit dönemi ve II. Meşrutiyet dönemi olarak bir dönemlendirmeye tabi tutmaktadır. Ayrıca Karpat'ın 19. yüzyıldan 20. yüzyılın ilk çeyreğine kadar hangi veçhelerle ve ne şekilde Osmanlılığın geldiğine dair ifade ettikleri de önemlidir (Karpat, 2009:607-652).
}

ve münakaşalar bu tezahürlerin sarahate kavuşmasında onlara fayda sağlamıştır. Osmanlılık, Türklük, İslamlık, muasırlaşma gibi fikirlerin temsil edildikleri mefhumlara dair farklı anlam dünyaları ihdas edilmeye gayret edilmiştir. Süleyman Nazif, Ahmet Ağaoğlu, Babanzâde Ahmet Naim, Ziya Gökalp gibi isimler bahsi geçen mefhumların sınırlarına dair fikirler ileri sürmüşler ve yer yer aralarında entelektüel zarafetin de temayüz ettiği tartışmalara girişmişlerdir. ${ }^{2}$

Osmanlılık/Osmanlıcılık fikrinin II. Meşrutiyet'in ilanını müteakip farklı siyasî anlamlar üzerinden eleştiriye tabi tutulduğu müşahede edilmektedir. Bu bakımdan ilk Türkçü parti olarak adlandırılabilecek olan Millî Meşrutiyet Fırkası'nın ortaya koyduğu yaklaşım dikkate değerdir. Tanzimat gazetesinde firkanın beyannamesinin özeti mahiyetinde neşredilen metinde Osmanlılığın merkezi sıkleti olarak Türklük ve İslamlığa işaret edilmesinin yanı sıra Arapların ve Arnavutların durumuna dair şu ifadelere yer verilmektedir: "Osmanlılığın merkezi sıkleti Türklük ve İslamlıkdır. Halbuki biz Türlüğü temsil eden Anadolu ile, Osmanlı tarihinden birer hisse-i mefhareti haiz olan Arabistan'ın ve Arnavutluk'un nasıl tahripkâr bir idareye tabi' olduğunu zi hayat vakayi' ile idrak ediyoruz."(Tanzimat,1328: 2)

Arnavutlar ve Osmanlılık meselesine dair Hüseyin Kazım Kadri'nin Arnavutluk'un bağımsızlığını müteakip bu hadiseye dair serdettiği fikirler oldukça kıymetlidir (Hüseyin Kazım, 1330). Nitekim; Osmanlılık/Osmanlıcılık düşüncesinin entelektüel mecralarda/mahfillerde gayri sahici unsurlar barındırdığını ihtiva eden bu fikirler aslında her ne kadar Osmanlılık/Osmanlıcılık düşüncesinin lafzen var olsa da ciddi bir zemin kaybı yaşamış olduğunun da önemli bir göstergesidir.

II. Meşrutiyet'in ardından gerek gayrimüslim unsurlarca sergilenen tavırlar gerekse Millî Meşrutiyet Fırkası mensuplarınca da ifade edilen Müslüman unsurlar arasında beliren yaklaşımlar Osmanlılık/Osmanlıcılık düşüncesinin gayri sahici olduğu yönündeki yaklaşımların pekişmesine imkân tanımıştır. $\mathrm{Bu}$ durum beraberinde Osmanlılık/Osmanlıcılık dışındaki fikri tezahürlerin belirgin hale gelmelerini sağlamıştır. Böylece önceleri mündemiç halde varlık gösteren Türklük, İslamlık ve Osmanlılık düşünceleri kendilerine mahsus bir mecra tutturmak adına daha sarih bir vaziyet almaya doğru evirilmişlerdir.

Osmanlılık/Osmanlıcılık düşüncesi her ne kadar II. Meşrutiyet sonrası süreçte geçer halini yitirmeye başlamışsa da Osmanlılık/Osmanlıcılık özelinde fikirler ileri sürülmeye devam edilmiştir. Elbette Osmanlılık/Osmanlıcılık düşüncesi

${ }^{2}$ Söz konusu duruma örneklik teşkil etmesi bakımından birçok örnek tartışmaya işaret etmek mümkündür. $\mathrm{Bu}$ bakımdan İçtihad yazarı Süleyman Nazif ile Türk Yurdu yazarı Ahmet Agayef arasında geçen tartışmalar dikkat çekicidir. BU tartışmalara örneklik teşkil etmesi bakımından bkz. (Süleyman Nazif, 1329:1645-1648; Süleyman Nazif, 1329: 1669-1672; Süleyman Nazif, 1329: 1732-1734; Süleyman Nazif, 1329: 1621-1623; Ahmet Agayef, 1329: 702-714). Bu tartışmaların dışında Babanzâde Ahmet Naim ile Ahmet Ağaoğlu arasında yaşanan İslam'da milliyet mefhumunun mülahaza edildiği tartışmaya da dikkat çekmekte fayda vardır. Tartışmanın muhtevası ve değerlendirmesi için bkz. (Kara, 2005: 290-308). 
sonraki yıllarda da varlığını liberal siyasi görüș sahiplerince ve dolayısıyla 19. yüzyılda beliren halinden emareler taşımaksızın sürdürmeye devam etmiştir. Nitekim; İstiklâl Harbi döneminde Peyam Gazetesi'nde Ali Kemal tarafından ileri sürülen düşünceler bu bakımdan dikkate değer bir biçimde karşımıza çıkmaktadır (Ali Kemal, 1338:1). Çalışmada; Osmanlılık/Osmanlıcılık düşüncesinin söz konusu dönemde Câmi’ Bey tarafindan ileri sürülen muhtevası esas tutularak, dönemin Osmanlılığa dair farklı fikri tezahürü faş edilmeye çalışılacaktır.

\section{Asker, Mebus, Muhalif, Gazeteci: Abdülkadir Câmi (Baykurt) Bey}

Abdülkadir Câmi Bey 1877 yılında İstanbul'da Hacı Mehmet Münir ve Ayşe Hanım'ın evladı olarak dünyaya gelmiştir. 1309 senesi Nisan ayında (M. 1893) Harbiye mektebine giren Câmi Bey buradan mezun olduktan sonra 38. Süvari birliğine tayin olunmuştur. 9 Ağustos 1897 tarihinde Trablusgarp'ta muallim sıfatıyla coğrafya derslerini icra eylemiş ve ardından da 1904 yılında Fizan ve Bingazi telgraf hatlarına dair başarılı çalışmalarından ötürü yüzbaşı vekilliği unvanıyla Trablusgarp kumandanlığı maiyeti yaverliği vazifesine getirilmiştir (Duman, 2015: 383). Câmi isminin kendisine verilmesi de bu döneme tesadüf eder. Trablusgarp kumandanlığı ve valiliği görevini ifa eden Recep Paşa birikimine atfen Molla Câmi'den mülhem olarak Câmi ismini kendisine verir ve bu tarihten itibaren Abdülkadir Câmi olarak bilinir (Demirel, 2008:184).

Câmi Bey'in Trablusgarp dönemine ilişkin birkaç hususa değinmekte fayda vardır: Bunlardan birincisi buraya yarı sürgün bir şekilde gittiğidir. Yılmaz; Câmi Bey’in hatıralarında Harbiye'de son sınıfta okuduğu dönemde kendi sınıflarının II. Abdülhamid'e sadakat noktasında şüpheli bir sinıf olarak mimlenmesi bu sinıfin tamamının mezuniyeti müteakip farklı yerlere sürgün gönderildiklerini nakletmektedir. İkincisi ise; Câmi Bey'in burada bulunduğu dönemde İttihatçılarla temasta bulunduğu ve hatta İttihat ve Terakki'nin kurucularından olan Abdullah Cevdet ile yoğun münasebetlerinin olduğudur (Yılmaz, 2008: 15). Tabi bu irtibat onun yakın gelecekte II. Meşrutiyet'in ilanını müteakip Fizan mebusu olmasının da imkânını doğurmuştur.

II. Meşrutiyet'in ardından İttihat ve Terakki mensubu olarak Meclis-i Mebusan'a Fizan mebusu sifatıyla seçilen Câmi Bey'in mebusluğuna yerel halktan biri olmadığı gerekçesiyle itirazlar söz konu olmuştur. 1909 Nisan ayında tekrarlanan seçimleri yeniden kazanan Câmi Bey'in İttihat ve Terakki ile olan münasebetinde 1910 yılı içerisinde kırılmaların yaşanmaya başladığını söylemek gerekmektedir. $\mathrm{Bu}$ kırgınlıklar aynı yıl içerisinde Câmi Bey'in İttihat ve Terakki'den ayrılmasına sebebiyet vermiştir (Yılmaz, 2008: 25-26). İttihat ve Terakkiden ayrıldığı dönemlerde Balkanlarda cereyan eden hadiselerin Câmi Bey üzerinde de aksülamelleri olmuştur. Bu tarihten sonra Câmi Bey ilk milliyetçi parti olarak kabul edilen Millî Meşrutiyet Fırkası'nın kurulmasına sebep olan fikrî temayüle duhul etmiş ve firkanın kurucuları arasında yer almıştır (Birinci, 2012: 195). Yeri gelmişken Câmi Bey ve Fırka ilişsisi üzerinden değişen fikrî yapıdan da kısaca bahsetmek gerekmektedir. İlk

\footnotetext{
${ }^{3}$ Yeni bir meclisin ihdas edilmesinin gerekçelerinin de ifade bulduğu söz konusu bu tamimin tam metni için bkz. Atatürk'ün Tamim, Telgraf ve Beyannameleri IV, Atatürk Kültür, Dil ve Tarih Yüksek Kurumu Atatürk Araştırma
}

olarak Millî Meşrutiyet Fırkası'nı teşkiline sebep hususlardan biri İttihat ve Terakki bünyesinde yaşanan anlaşmazlıktır. Ancak, buna ilave sebep olması bakımından firkanın kurulduğu tarihlerdeki siyasî vaziyet dikkate alındığında görülecektir ki; Osmanlı bünyesinde bulunan farklı unsurlar arasında ortaya çıkan tezahürler Türklük mefkûresine istinad eden bir fırka olarak Millî Meşrutiyet Fırkası'nın teşkilini sağlamıştır. Türklük ve İslamlıktan mülhem bir Osmanlılığ esas kabul etmelerinin yanı sıra İttihad-1 Anâsır (Birinci, 2012: 197) taraftarı olan Millî Meşrutiyet Fırkası'nın söz konusu bu tavrı kurucuları arasında yer alan Câmi Bey ve onun Osmanlılık özelinde serdettiği düşüncelerine ilişkin önem arz etmektedir.

Câmi Bey yukarıda ifade edilen ve ilk dönem şeklinde nitelendirilebilecek mebusluğunun ardından, Mayıs 1912'den Ağustos 1912 yılına kadar olan dönemde Meclis-i Mebusan'da tekrar Fizan mebusu olarak yer almıştır. Câmi Bey'in aktif siyasî hayatı son Osmanlı Mebusan Meclisi'nde mebus olarak bulunana kadar akamete uğramıştır. Buna rağmen bu zaman aralığında her ne kadar resmî olarak siyasetin içinde olmasa da daha sivil mecralarda sağladığı katkılarla siyasi faaliyetlerde bulunmaya devam etmiştir (Duman, 2015: 384-385). Mesela Mondros Mütarekesi'nin imzalanmasının akabinde İzmir'de kurulan İzmir Mudafaa-i Hukuk-1 Osmaniye Cemiyeti'nin çalışmalarına iştirak etmiş ve hatta Genel Sekreterlik vazifesinde bulunmuştur (Yılmaz, 2008: 40).

İstanbul'a avdetinin ardından Câmi Bey'e dair belirtilmesinde fayda olan bir diğer husus ise; Millî Ahrar Fırkası'nın kurucuları arasında yer almış olmasıdır(Millî Ahrar FırkasıBeyanname, Program, Nizamname-i Dahilî, 1335: 10). Kurucular arasında zikredilememekle birlikte Firka'nın teşkilinde yer alan Yahya Kemal'in aktardıklarına göre; Fırka'nın beyannamesinin hazırlanmasından kuruluş aşamasına getirilmesine kadar aktif olan isimlerin başında Câmi Bey gelmektedir (Yahya Kemal, 2017: 74-78). Demirel, Câmi Bey'in bu dönemdeki fikirlerini Bolșeviklik ve vahşi kapitalizm karşıtlığı üzerinden kurduğunu aktarmakta ve Batılı devletlerin Osmanlı'yı Rusya'ya feda ettikleri düşüncesinden hareketle Batılılarla Rusya özelinde karşılıklı çıkar esasına dayanan dengeli bir işbirliğinin sürdürülmesine inandığını aktarmaktadır. Ek olarak dünyada yaygın liberal anlayışın o dönemde Câmi Bey üzerinde de etkili olduğu bilgisini paylaşmaktadır (Demirel, 2008: 186).

Son Osmanlı Mebusan Meclisi'ne Aydın Mebusu olarak katılan Câmi Bey, Felâh-1 Vatan Grubu içerisinde yer almış (Uçar, 2011) ve daha sonra Karakol Cemiyeti'nin marifetiyle Halide Edip ve Adnan Adıvar ile Anadolu'ya geçmek durumunda kalmıștır (Adıvar, 1994: 70-74, 116,132-133, 135). Ankara'da toplanacak olan meclise dair Mustafa Kemal tarafindan yayınlanan tamimde Meclis-i Mebusan üyelerinin de bu meclise katılabilecekleri beyanına ${ }^{3}$ istinaden Câmi Bey'de bu çağrıya müspet karşılık vermiştir.

Câmi Bey Ankara'ya gelmesinin ardından toplanan Millet Meclisi'nin ilk Dahiliye Nazırı olarak görevlendirilmiş ve bu görevi kısa bir süre yürüttükten sonra Roma'ya Ankara

Merkezi, Ankara 2006; http://atam.gov.tr/wpcontent/uploads/tamim-son-Onar\%C4\%B11d\%C4\%B1.pdf.

Erişim Tarihi: 25. 12. 2018. 
hükümetini temsilen gönderilmiștir. ${ }^{4}$ Câmi Bey Roma'da bulunduğu süre zarfında Ankara hükümeti adına ciddi propaganda faaliyetleri yürütmüştür. Ankara hükümeti adına önemli faaliyetlerde bulunurken 1921 yılı kasım ayında görevine son verildi ve Türkiye'ye dönmesi yönünde çağrıda bulunuldu. Ancak Câmi Bey bu çağrılara uymadı ve devam eden milletvekilliği 21 Ekim 1922 yılında T.B.M.M tarafından nihayete erdirildi. Ülkeye avdeti İstanbul'un işgalinin son bulmasının ardından olan Câmi Bey'in bundan sonraki hayatı, aktif siyasi hayatın gerisinde fakat muhtelif gazetemecmualarda ve ideolojik mahfillerde oldukça etkin bir şekilde devam etmiştir (Demirel, 2008: 187-188).

Câmi Bey'in Türkiye'ye geldikten sonra vefatına kadar olan dönemde faşizm ve emperyalizm karşıtı bir söylem ve tavır içerisinde olduğunu belirtmek gerekir. Bu yönü ile Türkiye'de sol düşünce içerisinde yer almış ve sol düşünceye ait mahfillerde tercih etmiştir. Zekeriya Sertel tarafından çıkarılan Tan gazetesinde ${ }^{5}$ yazılar kaleme almış olması söz konusu duruma örneklik teşkil etmesi itibariyle kıymete haizdir. Câmi Bey'in bu döneminin sakin geçen bir dönem olmadığını belirtmekte de gerekmektedir. Kaleme aldığı metinler dolayısıyla çeşitli mahpusluklara da maruz bırakıldığı görülmektedir. 5 Eylül 1945 yılında Tan gazetesinde "Münevver Sınıfın Tarihi Rolü" serlevhalı aydın eleştirisi muhtevasıyla neşrettiği makalesi hapis cezası yatmasına sebebiyet vermiştir (Demirel, 2008: 189).

Osmanlı'dan Cumhuriyet'e Türk siyasî ve kültürel hayatında kendisine mahsus yeriyle dikkatleri çeken Câmi Bey'in hayatı genel olarak değerlendirildiğinde dönemsel farkl1lıklar gösteren bir hayat hikâyesi hüviyetindedir. Meşrutiyet öncesi dönemde Osmanlıcı bir söyleme sahipken meşrutiyetin ilanını müteakip dönemde Osmanlılığa ilave daha milliyetçi bir çizgiye kaymış, sonraları ise antiemperyalist ve faşizm karşıtı söylemleriyle daha sosyalist bir hüviyete bürünmüştür. Nitekim söz konusu farklı dönemlerde farklı fikirleri savunmak, dönemin aydınlarının büyük bir kısmında görülen bir tavirdır. ${ }^{6}$

İttihat ve Terakki Cemiyeti içerisinde bulunmuş olan Câmi Bey’in de görüldüğü üzere hayatında çeşitli fikri kaymalar ya da farklılaşmalar söz konusu olmuştur. II. Meşrutiyet dönemini müteakip daha Türkçü bir düşünceye evirilmiş ama yine de Osmanlılık özelinde fikirler serdetmeye devam etmiştir.

\footnotetext{
${ }^{4}$ Yılmaz, Câmi Bey’in Roma'ya elçi olarak tayini hususunda iki farklı iddiaya işaret etmektedir. Bunlardan birincisi Câmi Bey'in İtalyanlarla İstanbul'da münasebetinin yoğun olmasıdır. İkincisi iddia ise; Câmi Bey'in oğluna referansla İstanbul'dan uzaklaştırılmak istenmesidir (Yılmaz, 2008: 167).

5 Tan gazetesinin mahiyeti ve politik tavrına ilişkin bkz. (Öztekin, 2016).

6 II. Meşrutiyet dönemi öncesi ve sonrasında, Cumhuriyet ilanını müteakip dönemde fikri bakımdan farklılıklar sergileyen birçok isim zikredilebilir. Osmanlılıktan, Türkçülüğe ve sonraları sosyalizme kayan Ethem Nejat ve Osmanlıktan, Kürtçülüğe ve yeni kurulan devletle birlikte Cumhuriyetçiliğe doğru fikri yönelme sergileyen Abdullah Cevdet isimlerini zikretmek meseleyi vuzuha kavuşturması bakımından örnek olarak işaret edilebilecek isimlerdendir.
}

\subsection{Memleket Türk Arap Ekseriyeti Üzerine Istinad Etmelidir}

II. Meşrutiyet koşullarında önceleri İttihat ve Terakki bünyesinde siyasî faaliyetlerini yürüten Câmi Bey sonraları Millî Meşrutiyet Fırkası'nın teşekkülünde yer alarak fikrî vaziyetini de farklı veçhelere büründürmüştür. Yukarıda da ifade edildiği üzere Millî Meşrutiyet Fırkası kurulduğu vakitler her ne kadar milliyetçi-Türkçü bir teşebbüs olsa da dönemin baskın siyasî vaziyetinin bir gereği olarak Osmanlılığa dair bir misyonu ve vizyonu ortaya koymak durumunda kalarak Türklük ve İslamlıktan müteşekkil bir Osmanlılığın zarurî olduğunu resmi görüşü olarak beyan etmiştir. Câmi Bey'in ise II. Meşrutiyet koşullarında bu hususta önceleri makale olarak fakat sonraki yıllarda "Osmanlılığın Atisi" serlevhasıyla neşrettiği eserine aldığ 1 "Memleket Türk Arap Ekseriyeti Üzerine İstinad Etmelidir" başlıklı makalesi pratik anlamda geçerliliğini yitirmiş olan Osmanlılık düşüncesine ${ }^{7}$ getirdiği farklı yaklaşımla dikkatleri üzerine çekmektedir.

Câmi Bey'in Osmanlılık hususunda kaleme aldıklarında II. Meşrutiyet sonrası dönemde imparatorluk bünyesinde gerek Müslim gerekse gayrimüslim unsurlar arsında tezahür eden milliyetçi teşebbüslerin ve bu teşebbüsler dolayısıyla ortaya çıkan siyasî hadiselerin etkili olduğunu belirtmekte fayda vardır. Nitekim harici hadiseler Osmanlı Devleti ve Osmanlılık düşüncesi aleyhine cereyan ederken saltanat ve hilafetin gücünü Türk ve Arap unsurların barındırdığı imkândan alacaklarına işaret etmektedir. Bu bakımdan Câmi Bey makalesinin hemen başlangıcında bu meseleye şu cümlelerle işaret etmektedir: "Siyaset-i dahiliyeye gelince revabit-1 diniyye ve esaret-i ecnebiyeden azade olarak yaşamak kayd ve menfaati ile yekdiğerine merbut olacak Türk ve Arap kuvvetlerinin hâsıl edeceği ekseriyet üzerine müesses saltanat ve hilafet kuvvası daha ziyade metanet kesb edecektir.'( Fizan Meb’usu Sabıkı Câmi, 1331: 11). ${ }^{8}$

Türkler ve Arapların birlikteliğinden ibaret olması gerektiği iddia edilen Osmanlılığın teşekkülünde ise farklılıklara rıza göstermek ve hatta bu farklılıkları muhkem hale getirmek adına Araplara bir takım hakların verilmesinin elzem olduğu üzerinde hassaten durulmaktadır: "Ancak bu revabıtı tazyikat ile değil, zamanın icabatına nazaran bir takım tevziat ile teşyid ve takviye etmek icab eder."(s.11) Elbette bu gerekliliğe işaret etmenin dönemin siyasî vaziyetinin bir neticesi olduğunu

Ethem Nejat hayatı için bkz. (Erkek, 2012). Abdullah Cevdet'in hayatı için bkz. (Hanioğlu, 1981).

7 Osmanlılık düşüncesinin pratik anlamda geçerliliğini yitirdiği meselesine dair Teyfur Erdoğdu'nun ifade ettikleri dikkat çekicidir. Erdoğdu; II. Meşrutiyet'in ilanını müteakip dönemde sık1 Osmanlıcı olan İsmail Kemal Bey'in bağımsızlığının ardından Arnavutluk'un ilk başbakanı olmasını ve yine Osmanlılık fikrinin önemli bir savunucusu olan Satı el-Husri'nin Arap milliyetçiliğinin banilerinden biri haline gelmiş olmasını Osmanlılık fikrinin pratik anlamda nihayete erdiğinin ya da başarısızlığının bir göstergesi olarak imlemektedir (Erdoğdu, 2008: 38).

${ }^{8}$ Câmi Bey'in metnine ilişkin bundan sonraki atıflarda dipnot ile işaret etmek yerine metin içinde sayfa numarası parantez içinde verilecektir. 
ak1lda tutmak gerekmektedir. Nitekim makalenin kaleme alındığı tarihlerde Osmanlı Devleti'nin Müslim unsurları içerisinde batı kanadını temsil eden Arnavutların, istikballerinin tayini hususunda Osmanlı'dan gayri hareket etme iradesi göstermeleri ve bağımsızlıklarını ilan etmeleri temayüz etmiş Müslüman unsurlar olarak Türkler ve Arapların birlikteliğinin sağlanması hususunu zaruri olarak gündeme getirmiştir.

Câmi Bey’in Türkler ve Araplar özelinde arzuladığ Osmanlılığın gayesi olarak işaret ettiği mesele ise kendisinin Vatan-1 asliye-i Osmaniye olarak vurguladığı Balkanlar havalisinde Osmanlı düşmanlarınca ihdas edilmek istenen milliyet husumetlerini ta kökünden kesmek olarak belirtilmektedir. Türkler ile Arapların bir araya gelmesini gerekli kılan ya da buna imkân tanıyan belli başlı hususlara da vurgu yapılmaktadır. Bunlardan birincisi; "Osmanlı ülkesi içinde muayyen ve kat'i hudutlarla ayrılmış ve hiçbir zaman kavmiyet münaza'âtına saha olmayacak olan iki büyük kıt'a Anadolu ile bilad-1 Arabdır.'(s.11) ifadeleriyle Anadolu ve Arap havalisinde kavmiyet davası gütmenin esas mesele haline getirilemeyeceği şeklindedir. İkincisi ise; Türklerle Araplar arasında tarihî irtibatın ortaya çıkardığı ve Avrupa Siyasiyyununun garazkârane neşriyatına tahrif olunmayan tahkim edilmiş bir bağın olduğudur.

Câmi Bey’in vurguladığı bir diğer hususta Osmanlılığın teşekkülünde Türk ve Arap birlikteliğinin ne şekilde olması gerektiğidir. $\mathrm{Bu}$ bakımdan Araplar ve Türkler arasındaki ilișkinin eşitlik üzerine tesis edilmesi gerekliliği "Bundan sonra Osmanlı imparatorluğunun merkez sıkleti Türk ve Arab kuvvetlerinin hâsıl edeceği tevazundadır."(s.12) ifadeleri ile vurgulanmaktadır. Şunu da belirtmek gerekir ki söz konusu ifadelerden de anlaşılacağı üzere Devleti kurtarma isteğinin bir tezahürü Osmanlılığın ağırlık merkezi olarak Türk ve Arap birliğine işaret edilmekte ve diğer unsurlar için üstü kapalı da olsa daha tali bir konum tayin edilmektedir.

Türklük ve Araplık merkezli teşekkül edecek olan birlikteliğin temsil ettiği devletin merkezi idaresinin yerine dair de Câmi Bey’in ileri sürdüğü bir takım fikirler vardır. İstanbul'a atfedilen bir önem vardır ama dönemin siyasî vaziyetinin gereği olarak beliren Osmanlılığın (Türk-Arap) merkezi idaresinin hem bu ilişki dolayısıyla hem de siyasî ve askerî bir gereklilikten kaynaklı İstanbul dışında Anadolu ve Arap havalisine yakın bir yerde tesis edilmesi gerekliliği şu cümlelerle ifade bulmaktadır: "İstanbul her kuvvet bir belde-i (s. 12) sultaniye olmak üzere kalmakla beraber devlet-i Osmaniyenin, merkezi idare ve askeriyesini artık Türk ve Arab memalikinin hattı faslına nakl etmesi, Anadolu, Suriye, Irak ve müstakbel Kürdistan şimendiferlerinin mültekasında bir mahalde tesis eylemesi bir zaruret-i siyasiye ve askeriyenin neticesi olarak vakıa olacaktır."(s.13) Osmanlı idaresinin merkezine dair yapılacak bu değişikliğin siyasî ve askeri taraflarına işaret edilmenin yanı sıra iktisadî getirilerine de temas edilmektedir. Bu şekilde Anadolu ve Arap havalisi "kötü idareciler" tarafından maruz bırakıldıkları kötü durumdan kurtulacaklar ve bu durumda memleketin seviye-i iktisadiyesini ala edecektir. Bu noktada söz konusu metnin kaleme alındığı tarihlerde Arap havalisinde Araplık/Arap milliyetçiliği gayesini güden cemiyetler ve neşriyatlar özelinde muhtelif teşekküllerin var olduğu da bir gerçektir. ${ }^{9}$

\footnotetext{
${ }^{9}$ II. Meşrutiyet'in ilanını müteakip dönemde Arap unsurlarca
} kurulan ve Arap milliyetçiliği fikrinin tecessüm ettiği muhtelif
Hal böyle olunca Câmi Bey tarafından Türklük ve Araplıktan mülhem bir Osmanlılığa dair zikredilen düşünceler, onun meseleyi romantik bir bağlamda ele aldığı şeklinde değerlendirilebilir.

\section{Sonuç}

Osmanlı'da 19. Yüzyılın ikinci yarısından itibaren görünür olmaya başlayan yeni aydın/münevver sınıfının merkeze devleti kurtarmak ideali koymuş olması dolayısıyla daha gündelik sorunlara odaklanılmış, bu ise derinlikten uzak, eklektik ve sürekli değişken fikirler ileri sürmelerine sebebiyet vermiştir. Câmi Bey de hayatı boyunca vaziyet ettiği siyasî odaklardaki değişiklikleri ve fikri bakımdan dönem dönem farklı mecralarda yer almış olması hasebiyle söz konusu aydın grubu içerisinde değerlendirilebilecek bir isimdir. $\mathrm{Bu}$ bakımdan Osmanlılığa dair serdettiği fikirleri de Osmanlı Devleti'ni kurtarmak namına dönemin siyasî halinin ortaya çıkardığı fikirler olarak değerlendirmek mümkündür.

Câmi Bey, kökleri 19. yüzyılın ilk çeyreğine kadar götürülebilecek olan Osmanlılık/Osmanlıcılık düşüncesinin 20. Yüzyılın ilk çeyreğine doğru evirilmesine sebep olan gerekçelerin anlaşılmasına katkı sağlayan, II. Meşrutiyet dönemi aydınlarının bir örneği olarak görülebilecek isimlerdendir. Türklük ve Araplıktan mülhem bir Osmanlılık arzusunun Câmi Bey'in fikrî tekâmülü içerisinde dönemsel bir yer işgal ediyor olması bu iddiayı destekler mahiyettedir. Nitekim Osmanlılık adına ortaya koyduğu çerçevenin dönemin romantik vaziyetinin tezahürü olduğunu söylemek yanlış olmayacaktır. Hele de Arap havalisindeki milliyetçi tezahürlere rağmen bu birlikteliğin arzulanması aynı zamanda bir umudun tecellisi şeklinde de değerlendirilebilir. Osmanlı Devleti'nin merkezi idaresinin bu düşünce doğrultusunda değiştirilmesi talebinin gayri sahiciliği de benzer bir talep olarak ele alınabilir.

Nihaî olarak belirtmek gerekirse Câmi Bey II. Meşrutiyet ortamında unsurların bir bir kendi geleceklerini tayin etme noktasında irade göstermelerinden hareketle son umut olarak Türk ve Arapların birlikteliğini merkeze alan bir fikir ileri sürmüştür. Lakin sonraki dönemlerde bunun gayri sahiciliğini ortaya çıkan siyasî hadiseler üzerinden fark ederek daha farklı siyasî mevziler edinme yoluna gitmiştir.

\section{Kaynakça}

Adıvar, H. E. (1994), Türk'ün Ateşle Imtihanı, Atlas Kitapevi, İstanbul.

Ahmet Agayef (1329), "Sabık Trabzon Valisi Süleyman Nazif Beyefendi’ye”, Türk Yurdu, IV/21, 702-714.

Ali Kemal (1338), “Türklerin Tali'sizlikleri”, Peyam, 6/ 369127.

Atatürk'ün Tamim, Telgraf ve Beyannameleri IV, Atatürk Kültür, Dil ve Tarih Yüksek Kurumu Atatürk Araştırma Merkezi, Ankara 2006; http://atam.gov.tr/wpcontent/uploads/tamim-son-

Onar\%C4\%B1ld\%C4\%B1.pdf . Erişim Tarihi: 25. 12. 2018.

teşebbüsler hakkında Davut Hut tarafindan kaleme alınan makalede önemli bilgiler bulunmaktadır (Hut, 2016: 132-142) 
Birinci, A. (2012), Hürriyet ve İtilâf Fırkası, Dergâh Yayınları, İstanbul.

Çalen, M. K. (2013), "Bir Kimlik Siyaseti Olarak Osmanlıc1lı", Türk Yurdu, 33/308, 88-91.

Demirel, M. (2008), “Câmi Baykurt”, Modern Türkiye'de Siyasi Düşünce-Sol, Edt. Tanıl Bora-Murat Gültekingil, 8, İstanbul, 184-194.

Duman, O. Ö. (2015), “Meşrutiyet'ten Cumhuriyeti'e Parlemento Yaşamında Muhalif Bir Mebus "Câmi Baykut"”, Tarihin Peşinde, 13, 381-406.

Erdoğdu, A. T. (2008), “Osmanlılı̆̆ın Evrimi Hakkında Bir Deneme: Bir Grup (Üst Düzey Yönetici) Kimliğinden Millet Yaratma Projesine", Doğu Batı, 45, 19-46.

Erkek, M. S. (2012), Bir Meşrutiyet Aydını Ethem Nejat, Kitap Yayınevi, İstanbul.

Hanioğlu, Ş. (1981), Bir Siyasal Düşünür Olarak Abdullah Cevdet ve Dönemi, Üçdal Neşriyat, İstanbul.

Hikmet, Nu: 33, 1328, 2.

Hut, D. (2016), “Osmanlı Arap Vilayetleri, Arabizm ve Arap Milliyetçiliği”, Vakanüvis- Uluslararası Tarih Araştırmaları Dergisi, 1, ss. 105-150.

Hüseyin Kazım (Kadri) (1330), Arnavutlar Ne Yaptılar?, Yeni Turan Matbaası, İstanbul.

Kara, İ. (2005), Din Ille Modernleşme Arasında Çăgdaş Türk Düşüncesinin Meseleleri, Dergâh Yayınları, İstanbul.

Karpat, K. (2009), İslam'ın Siyasallaşması, İstanbul Bilgi Üniversitesi Yayınları, İstanbul.
Mardin, Ş. (1996), Yeni Osmanlılar Düşüncesinin Doğuşu, İletişim Yayınları, İstanbul.

Millî Ahrar Firkast- Beyanname, Program, Nizamname-i Dahilî, (1335), Şemseddin Matbaası, Dersaadet.

Öztekin, H. (2016), Tan: Serteller Yönetiminde Muhalif Bir Gazete, Tarih Vakfı Yurt Yayınları, İstanbul.

Somel, S. A. (2001), "Osmanlı Reform Çağında Osmanlıcılık Düşüncesi (1839-1913)", Modern Türkiye'de Siyasî Düşünce, 1, İstanbul, 88-98.

Süleyman Nazif (1329), "Ahmed Agayef Beyefendi'ye Cevap(I)", Ictihad, IV/ 76, 1669-1672.

(1329), "Ahmed Agayef Beyefendi'ye Cevap", Ictihad, IV/74, 1621-1623.

(1329), “Ahmed Agayef Beyefendi'ye Cevap", Ictihad, IV/75, 1645-1648.

(1329), “Ahmed Agayef Beyefendi'ye Cevap”, Ictihad, IV/79-2, 1732-1734.

Tunaya, T. Z. (1988), Türkiye'de Siyasal Partiler, Hürriyet Vakfi Yayınları, 2, İstanbul.

Uçar, A. (2011), Son Osmanlı Mebusan Meclisi ve Felâh-ı Vatan Grubu, Tekirdağ Üniversitesi Sosyal Bilimler Enstitüsü, Tekirdağ.

Yahya Kemal (2017), Tarih Musâhabeleri, İstanbul Fetih Cemiyeti Yayınları, İstanbul.

Yazıcı, N. (2002), Osmanlılık Fikri ve Genç Osmanlılar Cemiyeti, Kültür Bakanlığı Yayınları, Ankara.

Yılmaz, E. (2008), Dört Devirde Bir Muhalif Abdülkadir Câmi Baykurt (1877-1949), Türk Tarih Kurumu, Ankara. 